\title{
A Novel Approach Towards Green Synthesis of Nanodiamonds as Biocompatible Agents
}

\author{
A. Anand 1,*, M. Saran ${ }^{2,3}$, S. Chaudhary ${ }^{4}$, R.S. Ronin ${ }^{5}$, A.K. Swami ${ }^{3}$, M. Mathur ${ }^{5}$, \\ A. Burov 6,7, A. Bagaria $2, \dagger$ \\ ${ }^{1}$ Department of Biotechnology, Mewar University, 312901 Chittorgarh, India \\ 2 Department of Physics, Manipal University Jaipur, 303007 Jaipur, India \\ ${ }^{3}$ Department of Nanobiotechnology, Seminal Applied Sciences Pvt. Ltd, 302015 Jaipur, India \\ ${ }^{4}$ Department of Chemistry, Malviya National Institute of Technology, 302017 Jaipur, India \\ ${ }^{5}$ School of Agriculture, Suresh Gyan Vihar University, Mahal Road, 302017 Jaipur, India \\ ${ }^{6}$ Institute of Computational Technologies SB RAS, 660049 Krasnoyarsk, Russia \\ 7 Institute of Biophysics, SB RAS, Akademgorodok, 660036 Krasnoyarsk, Russia
}

(Received 11 January 2021; revised manuscript received 15 June 2021; published online 25 June 2021)

\begin{abstract}
The application of nanobiotechnology is an emerging area of nanoscience and nanotechnology. Nanodiamond has been a potent antibacterial, antifungal, antioxidant, and antiplatelet agent. In the present study, nanodiamonds were reduced by green synthesis and characterization was done through SEM, TEM, FTIR, and XRD. Further they were tested for their biological applications. The antimicrobial activity was investigated/studied/examined? through well diffusion method. The best activity was observed against Trichoderma reesei $(16 \mathrm{~mm})$ at $140 \mu \mathrm{g} / \mathrm{ml}$. The antioxidant activity was investigated through DPPH and FRAPS method. It was observed that the biologically reduced nanodiamonds reduce the $\mathrm{Fe}^{3+}$ ions to $\mathrm{Fe}^{2+}$ ions at $600 \mathrm{mM} / \mathrm{l} / \mathrm{g}$ concentration. In DPPH assay, inhibitory concentration was found to be $4.58 \mu \mathrm{g} / \mathrm{ml}$. Further the antiplatelet activity was investigated by prothrombin time (PT) and activated partial thromboplastin time (APTT) assay, and it was observed that biologically reduced nanodiamonds have potent antiplatelet activity.
\end{abstract}

Keywords: Nanodiamond, Antimicrobial, Green synthesis, Biocompatible agents, Antioxidants.

DOI: 10.21272/jnep.13(3).03040

PACS numbers: 81.07.Pr, 87.15.N -

\section{INTRODUCTION}

Nanodiamonds (NDs) are derived components of nanocarbons having diverse varieties based on conditions of synthesis, processes that are done after synthesis, and various other modifications. NDs have now attracted global attention due to their therapeutic bioefficacy in a variety of uses, including antimicrobial treatments, probes in diagnostic industries and even as delivery vehicles for anticancer drugs. Just like metal nanoparticles, quantum dots and carbon nanoparticles, NDs also have attractive properties that can be exploited in the similar manner [1-3].

When compared to microbial or chemical-based synthesis, green synthesis of nanoparticles is easier and much more efficient, and plant extracts can be a good alternative to chemical methods because they are cleaner and less toxic [4-7].

Moringa oleifera Lam. belongs to Moringaceae family with 14 species. Out of these $14, M$. oleifera is the one which is most commonly found. In India, this plant is also called as 'Sahanjana'. Pods and leaves of this plant contain about 2.5 and $6.7 \mathrm{~g}$ protein $/ 100 \mathrm{~g}$, respectively [8]. All the parts of this plant have their own medicinal values and are used in local remedies for different ailments ranging from cold and conjunctivitis to skin diseases [9-14]. It is also used as an ingredient in many Asian foods and has many traditional uses in medicine [15].

In both developing and developed countries, emer- gence and spread of antibacterial resistance is a growing problem which can become global crises. These include Gram-negative microbes which can cause enteric infections [16]. A strategy for the containment of resistance needs to be developed, applied, and evaluated. Such a strategy should focus on improving rational use of antimicrobials and reducing opportunities for spread of resistant organisms [17]. According to Gutierrez et al. [18], metallic nanoparticles are being explored as potential antimicrobials as they have been shown to have a function of the surface area in contact with microbes. They have been shown to have applications in textile industries, wastewater treatment, medical devices, food processing, packaging etc.

In living beings, free-radical synthesis is maintained by various molecules which could have endogenous origin, like catalase, glutathione peroxide as well as superoxide dismutase, [19] which significantly reduces the oxidation of the substrate [20]. They have different mechanisms, like inhibition of free radicals and complexation of metals [21].

The key advantage of natural antioxidants is that their intake is associated with reduced risks of cardiovascular diseases (CVD), diabetes, cancer, and other diseases associated with ageing [22]. Hence, in the current scenario, interest has increased considerably in finding naturally occurring antioxidants for use in foods or as medicinal compounds to replace synthetic antioxidants [23].

\footnotetext{
*manasm407@gmail.com

$\dagger$ ashima.bagaria@jaipur.manipal.edu

The results were presented at the International Conference on Multifunctional Nanomaterials (ICMN2020)
} 
Complex diseases like atherosclerosis can be cured by antioxidant-based nanodrug formulations [24], including many diseases ranging from diabetes to $\mathrm{Alz}$ heimer's and cancer [25-28].

Arterial thrombosis initiated by aggregation of platelets may result in angina and reclusion which can be life-threatening in nature. Therefore, inhibition of platelet aggregation is central in prevention and/or treatment of CVD [29]. Safety of synthetic drugs is not guaranteed but they have been shown to be potent in preventing the occurrence of CVD. At the initial stages of thrombosis (at the wound site), there is synthesis of von Willebrand factors and collagen which are adhesive proteins along with ADP and thrombin, which are soluble agonists that initiate platelet adhesion, activation, and aggregation leading to platelet-rich thrombus [30].

Melissa and Linhardt [31] explained that encapsulated nanoparticle-biomolecule composites are of interest due to their synergistic properties. For example, conjugated heparin (HP) has been investigated for both biological and chemical properties. The composite has a variety of enhanced biological activities.

\section{MATERIALS AND METHODS}

\subsection{Green Synthesis for Reduction of NDs}

The chemically prepared NDs were reduced biologically by using the fresh leaves of Moringa oleifera which were washed properly with distilled water.

$10 \mathrm{mg}$ NDs were suspended in $100 \mathrm{ml}$ distilled water and stirred on a magnetic stirrer. $5 \mathrm{~g}$ of Moringa leaves were grinded for $15 \mathrm{~min}$ and centrifuged at $4{ }^{\circ} \mathrm{C}$, $1000 \mathrm{rpm}$ for $5 \mathrm{~min}$. After centrifugation, the supernatant was collected and added to the flask containing the nanodiamond. Change in the solution was observed after overnight incubation indicating reduction of NDs.

\subsection{Antibacterial Activity}

Pure cultures of Staphylococcus aureus (MTCC No. 3381), Pseudomonas aeruginosa (MTCC No. 1688), E. coli (MTCC No. 443) and Bacillus subtilis (MTCC No. 10619) obtained were used as indicator organisms.

Antibacterial activity of the reduced NDs was investigated by agar well diffusion method [1-3]. The samples were loaded at different concentrations (prepared from stock solution of $1 \mathrm{mg} / \mathrm{ml}) 60 \mu \mathrm{g} / \mathrm{ml}, 80 \mu \mathrm{g} / \mathrm{ml}$, $100 \mu \mathrm{g} / \mathrm{ml}, 120 \mu \mathrm{g} / \mathrm{ml}, 140 \mu \mathrm{g} / \mathrm{ml}, 160 \mu \mathrm{g} / \mathrm{ml}$ Standard $(40 \mu \mathrm{g} / \mathrm{ml})$ with positive control as streptomycin. Zone of inhibition was measured by measuring the diameter of the zone after $24 \mathrm{~h}$ incubation at $37^{\circ} \mathrm{C}$.

\subsection{Antifungal Activity}

Microorganisms used: clinical laboratory bacterial isolates of Trichoderma reesei (ATCC 13631), Aspergillus niger (ATCC 9029), Penicillium funiculosum (ATCC 11797) and Fusarium oxysporum (ATCC 62506) were collected from the stock cultures of Microbiology Laboratory, SMS Medical College, Jaipur India.

Antifungal activity of the biologically reduced NDs was investigated by agar well diffusion method [4]. The samples at concentrations ranging from 60 to $160 \mu \mathrm{g} / \mathrm{ml}$ (prepared from stock solution of $1 \mathrm{mg} / \mathrm{ml}$ ) were loaded with Standard $(40 \mu \mathrm{g} / \mathrm{ml})$ with positive control as ketoconazole. Zone of inhibition was measured by measuring the diameter of the zone after $48 \mathrm{~h}$ incubation at $37^{\circ} \mathrm{C}$ and calculated by the formula:

Activity Index $=$ Zone of inhibition of sample / Zone of standard.

\subsection{Antioxidant Activity}

\subsubsection{DPPH (2,2-diphenyl-1-picrylhydrazyl)}

\section{Radical Scavenging Assay}

DPPH is used to evaluate antioxidant activity. It has also been used to quantify antioxidants in complex biological systems in recent years. The DPPH method can be used for solid or liquid samples and is not specific to any particular antioxidant component, but applies to the overall antioxidant capacity of the sample.

\subsubsection{FRAP (Ferric Reducing Antioxidant}

\section{Power) Assay}

FRAP assay is based on antioxidant activity when $\mathrm{Fe}^{3+}$ is reduced to $\mathrm{Fe}^{2+}$. Interaction with TPTZ gives a strong absorbance at $593 \mathrm{~nm}$ [5].

\subsection{Antiplatelet Activity}

Blood samples collected from SMS Medical College, Jaipur were centrifuged at $10.000 \mathrm{rpm}$ for $5 \mathrm{~min}$, from the centrifuged sample $200 \mathrm{ul}$ of platelet containing plasma was dissolved in isotonic $\mathrm{CaCl}_{2}$, and hemostatic parameters like prothrombin time (PT) and activated partial thromboplastin time (APTT) were measured [6].

Determination of PT and APTT: the blood clotting time was calculated, which gets triggered by incubation of plasma with the optimum amount of thromboplastin and calcium [7].

\section{RESULTS}

\subsection{Green Synthesis of NDs}

The plant extract of Moringa oleifera was prepared for the green synthesis of NDs using established protocols. The change in color from light green (a) to dark green (b) after the addition of NDs to the plant leaf extract indicated the formation of reduced nanoparticles (see Fig. 1).
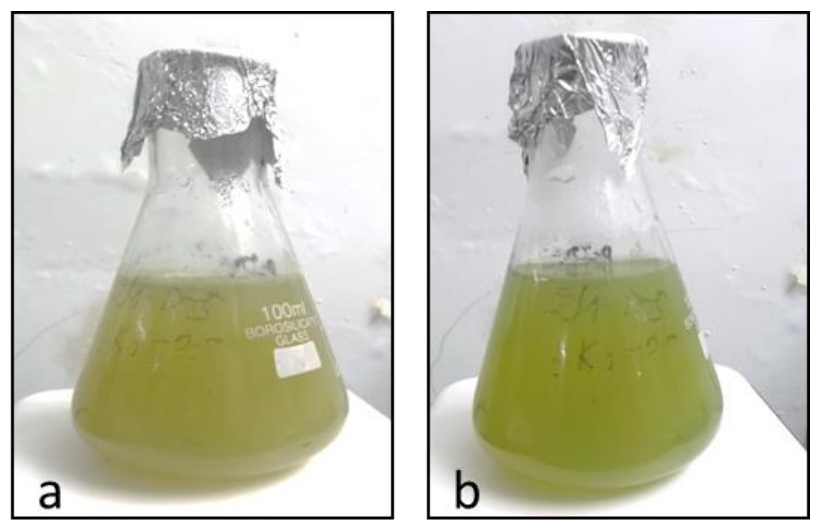

Fig. 1 - Reduction of NDs as shown by a slight change in color from light green (a) to dark green (b) 


\subsection{Characterization}

SEM and TEM were used initially. SEM image exhibited that the biosynthesized NDs were mostly spherical in shape. The average size of nanoparticles was confirmed by TEM to be around $100 \mathrm{~nm}$ which was in good agreement with SEM data (Fig. 2, Fig. 3).

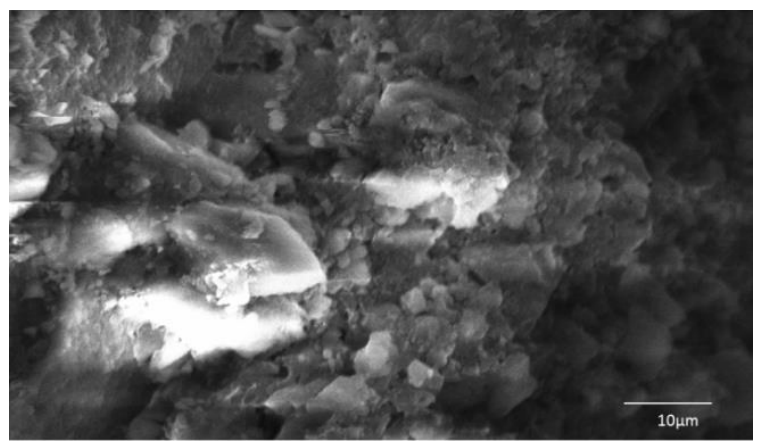

Fig. 2 - Scanning electron micrograph showing morphological appearance of reduced NDs

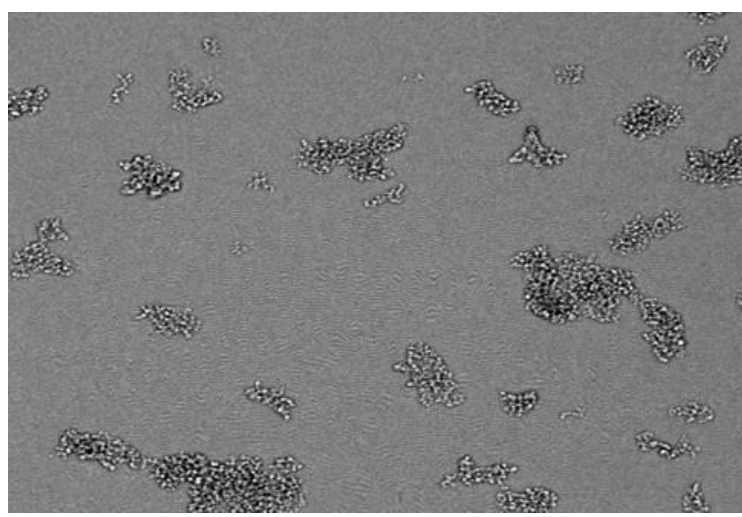

Fig. 3 - Transmission electron macrograph of reduced NDs

To identify the possible functional groups and other biomolecules involved in capping and reduction of newly doped NDs, FTIR was done. Fig. 4 shows the absorption bands at 3357, 1577, 1395, 1306, 1108, 1002, 975, $923,861,810,769,612$, and $406 \mathrm{~cm}^{-1}$. The strong peak at $3357 \mathrm{~cm}^{-1}$ corresponds to $\mathrm{N}-\mathrm{H}$ stretch $1^{\circ}, 2^{\circ}$ amines and amides. The band at $1577 \mathrm{~cm}^{-1}$ was attributed to $\mathrm{N}-\mathrm{H}$ bend $1^{\circ}$ amines. The peak at $1395 \mathrm{~cm}^{-1}$ corresponds to $\mathrm{C}-\mathrm{C}$ stretch (in-ring) aromatics and the peak at $1306 \mathrm{~cm}^{-1}$ corresponds to $\mathrm{C}-\mathrm{O}$ stretch alcohols, carboxylic acids, esters, ethers.

Further, peaks assigned at 1108 and $1002 \mathrm{~cm}^{-1}$ were due to $=\mathrm{C}-\mathrm{H}$ bend alkene. Other intense bands at 975 and $923 \mathrm{~cm}^{-1}$ belong to $\mathrm{O}-\mathrm{H}$ bend carboxylic acids. Further peaks at 861 and $810 \mathrm{~cm}^{-1}$ correspond to $\mathrm{C}-\mathrm{Cl}$ stretch alkyl halides. Further peaks at 769, 612 and $406 \mathrm{~cm}^{-1}$ also corresponded to alkyl halides.

To confirm the synthesis of NDs and to characterize their crystallinity and the phase pattern, XRD studies were carried out. The $2 \theta$ (in degrees) were in the range of $28.4^{\circ}$ to $66.5^{\circ}$. Four peaks at $2 \theta$ values of $29.76^{\circ}$, $38.76^{\circ}, 45.69^{\circ}$ and $55.48^{\circ}$ in counts per second were observed. The values of $2 \theta$ (in degrees) were in the range of 20.5-40.6 ${ }^{\circ}$, which confirms the reduction of NDs.

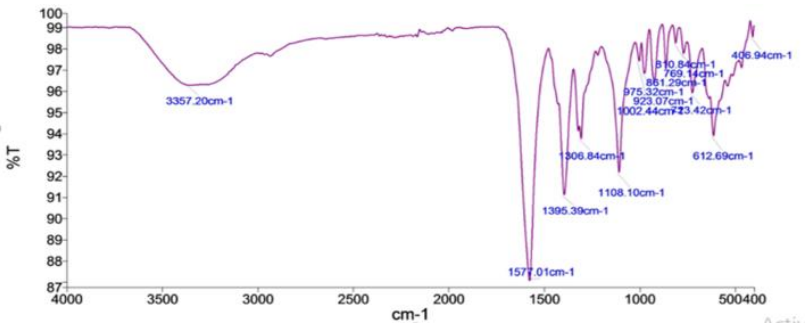

Fig. 4 - FTIR spectra of reduced NDs

These were compared with the JCPDS, $\mathrm{Cu}$ file no. 04-0836 which was in accordance with JCPDS standard. The XRD study confirms that the resultant particles were NDs. The nanopowder was found to be free of impurities because no other characteristic XRD peaks were observed. The formula used to calculate the average grain size of newly synthesized nanoparticles was based on the Debye-Scherrer formula

$$
D=K \lambda / \beta \cos \theta
$$

where $D$ is the average crystalline diameter size $(\AA), K$ is a constant (0.9), $\lambda$ is the wavelength of X-ray used $(k=1.54 \AA), \beta$ is the angular line width at the half maximum intensity (radians) and $\theta$ is the Bragg's angle (in degrees) (see Fig. 5).

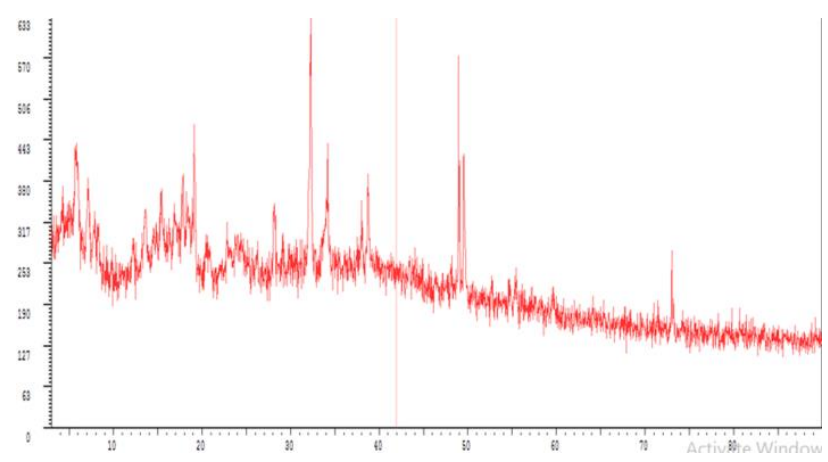

Fig. 5 - X-ray spectra of reduced NDs

\subsection{Antimicrobial Activity}

The reduced NDs showed potent antifungal activity at concentration ranging from 60 to $160 \mu \mathrm{g} / \mathrm{ml}$ on different species viz. Fusarium oxysporum, Penicillium funiculosum, Trichoderma reesei and Aspergillus niger. However, they did not show any antibacterial activity.

It was observed that with an increase in concentration of NDs, the size of the zone of inhibition in Trichoderma reesei increased, but in Penicillium funiculosum the scenario was the opposite. In case of Fusarium oxysporum NDs showed the zone of inhibition only at 60 and $120 \mu \mathrm{g} / \mathrm{ml}$. The maximum inhibition zone was observed at $120 \mu \mathrm{g} / \mathrm{ml}(16 \mathrm{~mm})$ against $P$. funiculosum, which was at par of $160 \mu \mathrm{g} / \mathrm{ml}$ against T. reesei, and the minimum zone was observed against A. niger at $120 \mu \mathrm{g} / \mathrm{ml}$.

\subsection{Antioxidant Activity}

In FRAP assay, the O.D. obtained on a spectrophotometer was then correlated with the standard FRAP curve. 
Table 1 - Antimicrobial (fungal) activity of biologically reduced NDs

\begin{tabular}{|c|l|l|l|l|}
\hline $\begin{array}{c}\text { Concentration } \\
\text { in }(\mu \mathrm{g} / \mathrm{ml})\end{array}$ & T. reesei & A. niger & $\begin{array}{l}\text { P. funic- } \\
\text { ulosum }\end{array}$ & $\begin{array}{l}\text { F. oxys- } \\
\text { porum }\end{array}$ \\
\hline 60 & - & - & - & $\begin{array}{l}\text { IZ-4 } \\
\text { AI-0.13 }\end{array}$ \\
\hline 80 & $\begin{array}{l}\text { IZ-10 } \\
\text { AI-0.27 }\end{array}$ & $\begin{array}{l}\text { IZ-6 } \\
\text { AI-0.23 }\end{array}$ & $\begin{array}{l}\text { IZ-8 } \\
\text { AI-0.23 }\end{array}$ & - \\
\hline 100 & & - & - & - \\
\hline 120 & $\begin{array}{l}\text { IZ-12 } \\
\text { AI-0.33 }\end{array}$ & $\begin{array}{l}\text { IZ-4 } \\
\text { AI-0.15 }\end{array}$ & $\begin{array}{l}\text { IZ-16 } \\
\text { AI-0.47 }\end{array}$ & $\begin{array}{l}\text { IZ-10 } \\
\text { AI-0.33 }\end{array}$ \\
\hline 140 & $\begin{array}{l}\text { IZ-14 } \\
\text { AI-0.38 }\end{array}$ & - & $\begin{array}{l}\text { IZ-12 } \\
\text { AI-0.35 }\end{array}$ & - \\
\hline 160 & $\begin{array}{l}\text { IZ-16 } \\
\text { AI-0.44 }\end{array}$ & - & $\begin{array}{l}\text { IZ-10 } \\
\text { AI-0.29 }\end{array}$ & - \\
\hline Standard 40 & 36 & 26 & 34 & 30 \\
\hline
\end{tabular}

Table 2 - Antioxidant activity of biologically reduced NDs through FRAP assay

\begin{tabular}{|c|l|}
\hline Samples & $\begin{array}{l}\text { Concentration required for reduction } \\
\text { of ferrous }\left(\mathrm{Fe}^{3+} \text { to } \mathrm{Fe}^{2+}\right)\end{array}$ \\
\hline 1 & $700 \mu \mathrm{M} / \mathrm{l} / \mathrm{g}$ \\
\hline
\end{tabular}

The FRAP value was found to be $700 \mu \mathrm{M} / \mathrm{l} / \mathrm{g}$. The percent of DPPH decoloration of the sample was calculated according to the formula:

$\%$ Decoloration $=[1-(A b s$ SAMPLE $/ A b s$ CONTROL $)] \times 100$.

The decoloration was plotted against the sample extract concentration, and a logarithmic regression curve was established in order to calculate IC $_{50}$ (inhibitory concentration 50, which is the amount of sample necessary to decrease by $50 \%$ the absorbance of DPPH). $\mathrm{IC}_{50}$ value in DPPH assay was found to be $4.58 \mu \mathrm{g} / \mathrm{ml}$.

Table 3 - Antioxidant activity of NDs using DPPH assay

\begin{tabular}{l|l} 
IC50 Value & $4.58 \mu \mathrm{g} / \mathrm{ml}$
\end{tabular}

\subsection{Antiplatelet Activity}

Prothrombin time (PT) assay.

When compared to control, all the extracts of NDs were able to prolong the clotting time. At $1 \mu \mathrm{gml}^{-1}$ (5 times of control and 12.33 times as compared to stan-

Table 4 - Antiplatelet activity of NDs using PT assay. Control - 37 sec. Standard (plasma + PT reagent) - 15 sec. *denotes potency of a sample at different concentration when compared with standard and control

\begin{tabular}{|c|c|c|c|}
\hline $\begin{array}{c}\text { Concentration of } \\
\text { sample }(\mu \mathrm{g} / \mathrm{ml})\end{array}$ & $\begin{array}{c}\text { Time in } \\
\text { seconds }\end{array}$ & Control & Standard \\
\hline 1 & 185 & 5.0 & 12.33 \\
\hline 2 & 58 & 1.56 & 3.86 \\
\hline 3 & 761 & 20.56 & 50.73 \\
\hline 4 & 48 & 1.29 & 3.2 \\
\hline 5 & 105 & 2.83 & 7 \\
\hline 6 & 874 & 23.62 & 58.26 \\
\hline 7 & 165 & 4.45 & 11 \\
\hline 8 & 1740 & 47.02 & 116 \\
\hline 9 & 58 & 1.56 & 3.86 \\
\hline 10 & 67 & 1.81 & 4.46 \\
\hline
\end{tabular}

Table 5-Antiplatelet activity of NDs using APTT assay. Control -47 sec. Standard (plasma $+\mathrm{CaCl}_{2}$ ) -40 sec. *denotes potency of a sample at different concentration when compared with standard and control

\begin{tabular}{|c|c|c|c|}
\hline $\begin{array}{c}\text { Concentration of } \\
\text { sample }(\mu \mathrm{g} / \mathrm{ml})\end{array}$ & $\begin{array}{c}\text { Time in } \\
\text { seconds }\end{array}$ & Control & Standard \\
\hline 1 & 185 & 5.0 & 12.33 \\
\hline 2 & 58 & 1.56 & 3.86 \\
\hline 3 & 761 & 20.56 & 50.73 \\
\hline 4 & 48 & 1.29 & 3.2 \\
\hline 5 & 105 & 2.83 & 7 \\
\hline 6 & 874 & 23.62 & 58.26 \\
\hline 7 & 165 & 4.45 & 11 \\
\hline 8 & 1740 & 47.02 & 116 \\
\hline 9 & 58 & 1.56 & 3.86 \\
\hline 10 & 67 & 1.81 & 4.46 \\
\hline
\end{tabular}

dard) good activity was observed. It increased slowly but at $10 \mathrm{\mu gml}^{-1}$ (1.81 times of control and 4.46 times of standard) was maximum. This was highly significant over both standard and control in all the cases.

Activated partial thromboplastin time (APTT) assay. When compared to control, all the extracts of NDs were able to prolong the clotting time. At $1 \mu \mathrm{gml}^{-1}$ (3.40 times of control and 4.05 times as compared to standard) good activity was observed. It increased slowly but at $10 \mu \mathrm{gml}^{-1}$ ( 0.40 times of control and 0.47 times of standard) was maximum. This was highly significant over both standard and control in all the cases.

\section{DISCUSSION}

Antibacterial activity of both silver nanoparticles and aqueous leaf extract was confirmed for Pseudomonas aeruginosa, Klebsiella spp, Staphylococcus aureus and Salmonella typhi by Kalaiselvi et al. [8]. The difference is thought to be due to difference in chemical behavior of diamonds. Kandile et al. [9] reported that the nanoparticles had effect on antimicrobial and antifungal activity of new heterocycles. These activities were investigated using the disk diffusion method. The strongest antifungal activity was seen against Aspergillus flavus. Galli et al. [10] showed that the NDs have the most disparate origins and reported stability, structural and electronic properties of NDs.

During oxidation, reactive oxygen species (ROS) are produced but excessive accumulation of ROS results in damage to cells, proteins and DNA [11]. These cause a variety of diseases including cellular aging, mutagenesis, carcinogenesis, hepatopathies, diabetes, and neurodegeneration [12]. Therefore, cellular antioxidant defense systems play important roles in counteracting these deleterious effects of ROS.

ROS are continuously produced in cells as a consequence of biochemical oxidative reactions or external factors [43]. These include free radicals, as the superoxide anion $\left(\mathrm{O}_{2}\right)$ and the hydroxyl radical $(-\mathrm{OH})$, and free non-radical species, as $\mathrm{H}_{2} \mathrm{O}_{2}$ and singlet oxygen $\left({ }^{1} \mathrm{O}_{2}\right)$ [44]. Oxidative stress induced by oxygen radicals promotes damage to essential biomolecules such as carbohydrates, proteins, amino acids, lipids, nucleic acids among other oxidative substances [45], thus contributing to aging and installation of chronic-degeneration 
diseases, such as cancer, CVD, arthritis, gastric ulcer, among others [46, 47].

Kalaiselvi et al. [38] reported synthesis and characterization of silver nanoparticles from leaf extract of Parthenium hysterophorus and its antioxidant activity. The antioxidant property was determined using DPPH (1, 1-diphenyl-2-picrylhydrazyl) assay and hydrogen peroxidase assay. The antioxidant property was found to be better for the aqueous leaf extract and the extract containing metal particles which was also observed in case of NDs in our present investigation.

The antioxidant power is counted in "Trolox equivalents"; the antioxidant power appears as the ability to prevent induced damage to fluorescein [48]. The ferric reducing antioxidant power (FRAP) assay is another method of wide suitability for assay of antioxidants in vitro as well as in organisms [49]. This assay is based on the reduction of $\mathrm{Fe}^{3+}$ to $\mathrm{Fe}^{2+}$ due to the action of antioxidants present. Subsequently, the $\mathrm{Fe}^{2+}$ formed may interact with 2, 4, 6-tris (2pyridyl)-s-triazine (TPTZ) providing a strong absorbance at $593 \mathrm{~nm} \mathrm{[50].}$ Some earlier reports on evaluation of antioxidant po-

\section{REFERENCES}

1. R.A. Freitas Jr, Nanomedicine, Volume Iia: Biocompatibility (CRC Press: 2003).

2. A. Bianco, Expert Opin. Drug Deliv. 1, 57 (2004).

3. A. Bianco, J. Hoebeke, K. Kostarelos, M. Prato, C.D. Partidos, Curr. Drug Deliv. 2, 253 (2005).

4. A.M. Abdelmonem, R.M. Amin, Int. J. Sci.: Basic Appl. Res. (IJSBAR) 15, 57 (2014).

5. M. Saran, S. Vyas, M. Mathur, A. Bagaria, IET Nanobiotechnol. 12, 357 (2017).

6. K. Kumar, M. Saran, L. Yadav, B.R. Kumar Shyamlal, M. Mathur, A. Bagaria, S. Chaudhary, Chem. Select 3 No 48, 13716 (2018).

7. A.K. Sharma, A.K. Swami, D. Jangir, M. Saran, T. K. Upadhyay, R.K. Prajapat, D. Sharma, M. Mathur, Gazi Medical J. 31, 719 (2020).

8. S.C. Verma, R. Banerji, G. Misra, S.K. Nigam, Curr. Sci. 45 No 21, 769 (1976).

9. J.L. Hartwell, A Survey Lloydia 30, 379 (1967).

10. B.S. Rathi, S.L. Bodhankar, A.M. Baheti, Indian J. Exp. Biol. 44, 898 (2006).

11. M.R. Sulaiman, Z.A. Zakaria, A.S. Bujarimin, M.N. Somchit, D.A. Israf, S. Moin, Pharm. Biol. 46, 838 (2008).

12. B. Agrawal, A. Mehta, Indian J. Pharmacol. 40, 28 (2008).

13. S. Fakurazi, U. Nanthini, I. Hairuszah, Int. J. Pharmacol. 4, 270 (2008)

14. A.P. Guevara, et al., Mutat. Res. Gen. Tox. En. 440, 181 (1999).

15. F. Anwar, S. Latif, M. Ashraf, A.H. Gilani, Phytother. Res. 21 , 17 (2007).

16. S. Saeed, P. Tariq, Pak. J. Pharm. Sci. 20, 32 (2007).

17. A. Bryskier, Expert Opin Investig Drugs 8, 1171 (1999).

18. F.G. Martinez, et al., Nanomedicine 6, 681 (2010).

19. S.M.D. Morais, E.S.B. Cavalcanti, S.M.O. Costa, L.A. Aguiar, Rev. Bras. Farmacogn. 19, 315 (2009).

20. C.D.M. Sousa, et al., Química Nova 30, 351 (2007).

21. J.M. Duarte-Almeida, R.J. dos Santos, M.I. Genovese, F.M. Lajolo, Ciencia Tecnol. Alime 26, 446 (2006).

22. K. Kamiya, Y. Tanaka, H. Endang, M. Umar, T. Satake, J. Agric. Food Chem. 52, 5843 (2004).

23. N. Ito, S. Fukushima, A. Haqlwara, M. Shibata, T. Ogiso, J. Natl. Cancer Inst. 70, 343 (1983).

24. B. Dursun, E. Dursun, I. Capraz, T. Ozben, A. Apaydin, G. Suleymanlar, J. Invest. Med. 56, 545 (2008).

25. Y. Minamiyama, et al, Biofactors 30, 91 (2007). tential using FRAP assay includes [51, 52]. In our present investigation, significant antioxidant activity was observed in terms of FRAP assay.

Natural anticoagulants without any side effects are gaining increasing attention. Hong et al. [53] also advocates for new approaches that can be used to analyze and evaluate the drug-receptor binding under laboratory settings. Inhibition of both the platelet aggregation and anticoagulants by using phytoceuticals and nutraceuticals can be used for the prevention of thrombosis.

To the best of our knowledge, this is the first comprehensive report on various biological parameters of reduced NDs.

\section{ACKNOWLEDGEMENTS}

The authors are thankful to Manipal University Jaipur, Mewar University and Seminal Applied Sciences for providing the necessary facilities to carry out the research work. Authors thank Prof. Andrey Burov, Department of Biophysics, St. Petersburg State University, Russia for providing carbon-based nanoparticles.

26. D.H. Setiadi, G.A. Chass, L.L. Torday, A. Varro, J.Gy. Papp, J. Mol. Struc-Theochem. 620, 93 (2003).

27. A.B. Weitberg, J. Exp. Clin. Cancer Res. 26, 583 (2007).

28. M.K. Rakha, Z.I. Nabil, A.A. Hussein, J. Med. Food 11, 91 (2008).

29. Y.R. Jin, et al., Atherosclerosis 194, 144 (2007).

30. S.P. Jackson, W.S. Nesbitt, S. Kulkarni, J. Thromb. Haemost. 1, 1602 (2003).

31. M.M. Kemp, R.J. Linhardt, WIREs Nanomed. Nano-biotechnol. 2, 77 (2010)

32. O. Irobi, J. Pharmacol. 34, 87 (1996).

33. A.K. Sharma, Int. J. Pharm. Sci. 11, 4070 (2020).

34. N. Sardana, K. Singh, M. Saharan, D. Bhatnagar, R.S. Ronin, J. Int. Sci. Technol. 6, 1 (2018).

35. C. Malarkodi, G. Annadurai, Appl. Nanosci. 3, 389 (2013).

36. I.S. Varga, B. Matkovics, Pathophysiology 5, 77 (1998).

37. E. Perlick, Gerinnungslaboratorium in Klinik und Praxis (Thieme: 1960)

38. J.J. Antony, et al., Colloid. Surf. B 109, 20 (2013).

39. N.G. Kandile H.T. Zaky, M.I. Mohamed, H.M. Mohamed, Bull. Korean Chem. Soc. 31, 3530 (2010).

40. G. Galli, Structure, Stability and Electronic Properties of Nanodiamonds. Computer-Based Modeling of Novel Carbon Systems and Their Properties. Carbon Materials: Chemistry and Physics, 3 (L. Colombo, A. Fasolino) (Springer: Dordrecht: 2010).

41. O. Blokhina, K.V. Fargestedt, Physiol. Plant. 138, 447 (2010).

42. J. Moskovitz, M.B. Yim, P.B. Chock, Arch. Biochem. Biophys. 397, 354 (2002).

43. A. Russo, R. Longo, A. Vanella, Fitoterapia 73, S21 (2002).

44. J. Borgo, et al., Rev. Bras. Farmacogn. 20, 12 (2010).

45. F. Sharififar, M.H. Moshafi, S.H. Mansouri, M. Khodashenas, M. Khoshnoodi, Food Control. 18, 800 (2007).

46. A. Kumaran, R.J. Karunakaran, LWT-Food Sci. Technol. 40, 344 (2007).

47. G.D. Silva, et al., Rev. Bras. Farmacogn. 19, 530 (2009).

48. D. Huang, B. Ou, R.L. Prior, J. Agric. Food Chem. 53, 1841 (2005).

49. L.M. Magalhães, M.A. Segundo, S.R. José, L.F.C. Lima, Anal. Chim. Acta 613, 1 (2008).

50. A. Szydłowska-Czerniaka, C. Dianoczki, K. Recseg, G. Karlovits, E. Szłyka, Talanta 76 No 4, 899 (2008).

51. O. Politeo, M. Jukić, M. Miloš, Croat. Chem. Acta 79, 545 (2006). 
52. P. Paśko, H. Bartoń, P. Zagrodzki, S. Gorinstein, M. Fołta, Z. Zachwieja, Food Chem. 115, 994 (2009).
53. Hong Nie, Lan-zhen Meng, Hui Zhang, Jian-yu Zhang, Zhen Yin, Xue-song Huang, Chin. Med. J. (Engl) 121, 1226 (2008).

\title{
Новий підхід до зеленого синтезу наноалмазів як біосумісних агентів
}

\author{
A. Anand ${ }^{1}$, M. Saran ${ }^{2,3}$, S. Chaudhary 4 , R.S. Ronin ${ }^{5}$, A.K. Swami ${ }^{3}$, M. Mathur 5 , \\ A. Burov 6,7, A. Bagaria ${ }^{2}$ \\ 1 Department of Biotechnology, Mewar University, 312901 Chittorgarh, India \\ ${ }^{2}$ Department of Physics, Manipal University Jaipur, 303007 Jaipur, India \\ ${ }^{3}$ Department of Nanobiotechnology, Seminal Applied Sciences Pvt. Ltd, 302015 Jaipur, India \\ ${ }^{4}$ Department of Chemistry, Malviya National Institute of Technology, 302017 Jaipur, India \\ 5 School of Agriculture, Suresh Gyan Vihar University, Mahal Road, 302017 Jaipur, India \\ ${ }^{6}$ Institute of Computational Technologies SB RAS, 660049 Krasnoyarsk, Russia \\ ${ }^{7}$ Institute of Biophysics, SB RAS, Akademgorodok, 660036 Krasnoyarsk, Russia
}

\begin{abstract}
Застосування нанобіотехнологій є новою сферою нанонауки та нанотехнології. Наноалмаз є потужним антибактеріальним, протигрибковим, антиоксидантним та антитромбоцитарним матеріалом. У дослідженні наноалмази були відновлені шляхом зеленого синтезу, а характеризування проводилося за допомогою SEM, TEM, FTIR та XRD. Далі наноалмази перевіряли для використання у біологічних додатках. Протимікробну активність вивчали методом дифузійної свердловини. Найкраща активність спостерігалася щодо Trichoderma reesei (16 мм) при 140 мкг/мл. Антиоксидантну активність досліджували за допомогою методів DPPH та FRAPS. Було помічено, що біологічно відновлені наноалмази відновлюють іони $\mathrm{Fe}^{3+}$ до іонів $\mathrm{Fe}^{2+}$ при концентрації $600 \mathrm{mM} / л / г$. Аналіз $\mathrm{DPPH}$ виявив, що концентрація інгібітора становить 4,58 мкг/мл. Антитромбоцитарну активність досліджували за допомогою аналізу протромбінового часу (РТ) та активованого часткового тромбопластинового часу (AРТT) і спостерігали, що біологічно відновлені наноалмази мають потужну антитромбоцитарну активність.
\end{abstract}

Ключові слова: Наноалмаз, Антимікробний, Зелений синтез, Біосумісні агенти, Антиоксиданти. 